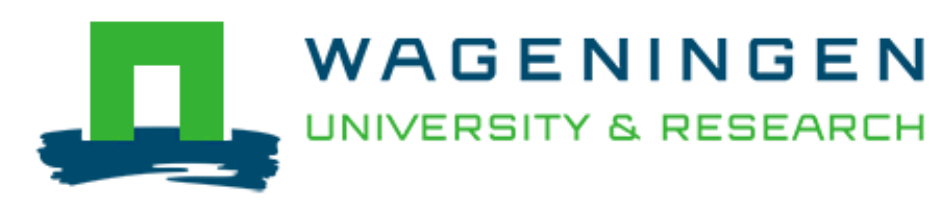

\author{
Assessing environmental consequences of using co-products in animal feed \\ van Zanten, H.H.E.; Mollenhorst, H.; de Vries, J.W.; van Middelaar, C.E.; van \\ Kernebeek, H.R.J.; de Boer, I.J.M.
}

This is a "Post-Print" accepted manuscript, which has been published in "The International J ournal of Life Cycle Assessment"

This version is distributed under a non-commercial no derivatives Creative Commons (c) (1) () $\Theta$ (CC-BY-NC-ND) user license, which permits use, distribution, and reproduction in any medium, provided the original work is properly cited and not used for commercial purposes. Further, the restriction applies that if you remix, transform, or build upon the material, you may not distribute the modified material.

Please cite this publication as follows:

van Zanten, H.H.E.; Mollenhorst, H.; de Vries, J.W.; van Middelaar, C.E.; van Kernebeek, H.R.J .; de Boer, I.J.M. (2014) Assessing environmental consequences of using co-products in animal feed. The International J ournal of Life Cycle Assessment, 19(1), 79-88. DOI : 10.1007/s11367-013-0633-X

You can download the published version at:

http://dx.doi.org/10.1007/s11367-013-0633-x 


\title{
Assessing environmental consequences of using co-products in animal feed
}

\author{
H.H.E. van Zanten ${ }^{1,2, *}$, H. Mollenhorst ${ }^{1,3}$, J.W. de Vries ${ }^{1}$, C.E. van Middelaar ${ }^{1}$, H.R.J. van Kernebeek ${ }^{1}$ and I.J.M. \\ de Boer $^{1}$
}

${ }^{1}$ Animal Production Systems Group, Wageningen University, PO Box 338, 6700 AH Wageningen, the Netherlands ${ }^{2}$ Wageningen UR Livestock Research, Wageningen University and Research Centre, PO Box 135, 6700 AC Wageningen, The Netherlands

${ }^{3}$ Business Economics Group, Wageningen University, PO Box 8130, 6700 EW Wageningen, the Netherlands

*Corresponding author: Hannah van Zanten. E-mail: hannah.vanzanten@wur.nl

\begin{abstract}
Purpose: The livestock sector has a major impact on the environment. This environmental impact may be reduced by feeding agricultural co-products (e.g. beet tails) to livestock, as this transforms inedible products for humans into edible products, e.g. pork or beef. Nevertheless, co-products have different applications such as bio-energy production. Based on a framework we developed, we assessed environmental consequences of using co-products in diets of livestock, including the alternative application of that co-product. Method: We performed a consequential life cycle assessment, regarding greenhouse gas emissions (including emissions related to land use change) and land use, for two case studies. Case 1: Increasing the use of wheat middlings in diets of dairy cattle at the expense of using it in diets of pigs. The decreased use of wheat middlings in diets of pigs was substituted with barley, the marginal product. Case 2: Increasing the use of beet tails in diets of dairy cattle at the expense of using it to produce bio-energy. During the production of biogas, electricity, heat, and digestate (that is used as organic fertiliser) were produced. The decrease of electricity and heat was substituted with fossil fuel, and digestate was substituted with artificial fertiliser. Results and discussion: Using wheat middlings in diets of dairy cattle instead of using it in diets of pigs resulted in a reduction of $329 \mathrm{~kg} \mathrm{CO}$-eq per ton wheat middlings and a decrease of 169 $\mathrm{m}^{2}$ land. Using beet tails in diets of dairy cattle instead of using it as a substrate for anaerobic digestion resulted in a decrease of $239 \mathrm{~kg} \mathrm{CO}_{2}$-eq per ton beet tails and a decrease of $154 \mathrm{~m}^{2}$ land. Emissions regarding land use change contributed significantly in both cases but had a high uncertainty factor, \pm 170 ton $\mathrm{CO}_{2} \mathrm{ha}^{-1}$. Excluding emissions
\end{abstract}


from land use change resulted in a decrease of $9 \mathrm{~kg} \mathrm{CO}$ for case 1 'wheat middlings' and an increase of $50 \mathrm{~kg}$ $\mathrm{CO}_{2}$-eq for case 2 'beet tails'. Conclusion: Assessing the use of co-products in the livestock sector is of importance because shifting its application, can reduce the environmental impact of the livestock sector. A correct assessment of the environmental consequences of using co-products in animal feed should also include potential changes in impacts outside the livestock sector, such as the impact in the bio-energy sector.

Keywords: consequential LCA, co-product, pigs, dairy cattle, livestock feed, bio-energy, land use change 


\section{Introduction}

Current livestock production levels pose severe pressure on the environment via their emissions to air, water and soil (Tilman et al. 2001; Steinfeld et al. 2006). The livestock sector also competes increasingly for scarce resources such as land, water, and fossil energy (Steinfeld et al. 2006; De Vries and De Boer 2010). The challenge, therefore, is to reduce emissions to the environment and to increase efficient use of scarce resources per kg of animal-source food produced. The environmental impact of livestock production results mainly from production and utilization of feed (Van der Werf et al. 2005; Elferink et al. 2008; De Vries and De Boer 2010). A possible way to reduce the impact of livestock production is feeding co-products from, for example, arable production or the food processing industry to livestock. Examples of co-products are wheat middlings, a co-product from wheat cultivated to produce wheat flour, or beet tails, a co-product from sugar beets cultivated to produce sugar. As most emissions or resources used, for example during crop cultivation or processing, are ascribed to the main product that economically drive these production stages, the environmental impact of an untreated co-product is according to Elferink et al. (2008) relatively low. Furthermore, most co-products are inedible for humans or do not meet Dutch food requirements, such as taste and texture. Therefore, feeding co-products to livestock transforms an inedible product into an edible product, such as meat, milk, and eggs (Fadel 1999; Elferink et al. 2008; Garnett 2009).

Some co-products are used in diets of livestock (Nonhebel 2007; Elferink et al. 2008; Vellinga et al. 2009). Vellinga et al. (2009) showed that in the Netherlands in 2007, the amount of co-products used in diets of livestock was $22 \%$. The current motivation to use co-products in diets of livestock, however, depends on a combination of their nutritional value and cost price, and is not driven by environmental motives. Elferink et al. (2008) concluded that for all Dutch citizens about $81 \mathrm{~g}$ of pork per day can be produced, while using all co-products from the sugar beet, vegetable oil, and potato industry, which represent approximately $60 \%$ of the co-products produced from the food industry in the Netherlands. When corrected for the total share of co-products in feed produced in the Netherlands, enough pig meat can be produced to fulfil the amount of animal protein advised by the Dutch health organizations, while the environmental impact per kg of meat produced decreased (Elferink et al. 2008). However, we should take into account that, besides feed, co-products might have other applications, such as production of bio-energy, or can be fed to other species. Increasing the use of a co-product in animal feed inherently implies decreasing the availability of that co-product for other applications as the production of the co-product is determined by the main product that economically drives the production stages. In the Netherlands, for example, there is a competition between animal feed and bio-energy production for wet co-products, such as beet tails and potato peels (Koppejan et al. 2009). Increasing the use of co-products in the livestock sector, therefore, may have 
an environmental impact on processes outside the production cycle of the livestock sector, e.g. on processes in the bio-energy industry. That impact needs to be considered when evaluating the environmental impact of using coproducts in the livestock sector.

The goal of this paper was to assess the overall environmental consequences of increasing the use of co-products in diets of livestock, including environmental consequences for the alternative application of that co-product. We used consequential life cycle assessment (CLCA) to illustrate the overall consequences for two Dutch case studies, regarding global warming potential (GWP) and land use (LU). In the first case, we analysed the consequences of increasing the use of wheat middlings in diets of dairy cattle at the expense of using it in diets of pigs, whereas in the second case we analysed the consequences of increasing the use of beet tails in diets of dairy cattle at the expense of using it to produce bio-energy. These cases were of interest as both co-products are used as energy source in livestock feed, and, therefore, are comparable with respect to feed requirements. Furthermore, both coproducts are used as dairy cattle feed but they differ in their alternative application. Wheat middlings are used in pig feed but can be used in dairy cattle feed as well. Beet tails are used in the bio-energy sector (De Vries et al. 2012b) but can be used in dairy cattle feed as well.

\section{Methods}

\subsection{Consequential life cycle assessment}

Life cycle assessment (LCA) is an internationally accepted and standardized holistic method (ISO14040 1997; ISO14041 1998; ISO14042 2000; ISO14043 2000) to evaluate the environmental impact during the entire production chain (Guinée et al. 2002; Bauman and Tillman 2004). In this study, we focussed on LU and GWP (including emissions from land use change (LUC)).

Two types of LCA exist: attributional LCA (ALCA) and consequential LCA (CLCA). Attributional LCA describes the environmentally relevant physical flows to and from a product or process, while CLCA describes how environmental flows change in response to a change in the system (Ekvall and Weidema 2004). As our aim was to determine environmental consequences of a change in use of co-products, we performed a consequential LCA. The starting point in our CLCA was a multifunctional process, an activity that fulfils more than one function (Ekvall and Finnveden 2001), yielding two products: the determining product, which determines the production volume of that process, and a co-product (Weidema and Ekvall 2009). A change in demand of the determining 
product directly affects the production volume of the co-product, and subsequently the production of the product that is displaced by that co-product (Weidema and Ekvall 2009). Within CLCA, system expansion is generally used to deal with multifunctional processes. System expansion implies that you include changes in the environmental impact of the alternative production process for which the co-product could be used, into your analysis by subtracting the impact related to the alternative production process (Ekvall and Finnveden 2001). Weidema and Ekvall (2009) developed a framework to ascribe the environmental impact of a multifunctional process to various outputs, based on system expansion. Their framework, however, was based on the assumption that the demand for the determining product or co-product increased, or in other words, the total amount of available co-product increased. In our analysis, however, we assumed a stable market situation. We wanted to assess the consequences of changing the application of a co-product, while the demand remained equal. When the demand for both the determining product and co-product remained equal, the total amount of available co-product remained equal as well. In this way, we could analyse what the optimal use of a co-product is from an environmental perspective. Therefore, we extended the framework of Weidema and Ekvall (2009) to allow an analysis of the environmental consequences of a change in application of a co-product, for example, a change from application in bio-energy production to application in diets of livestock. The extended framework is explained in paragraph 2.4 .

\subsection{Case description}

Two co-products, i.e. wheat middlings and beet tails, were selected as cases to illustrate our extended framework.

\subsubsection{Case 1: Wheat middlings}

Milling of wheat results in the production of wheat flour used for human consumption (the determining product) and wheat middlings (the co-product). The production volume of wheat middlings, therefore, is determined by the demand for wheat flour.

In this case study, we illustrated the environmental consequences of increasing the use of wheat middlings with one ton in diets of dairy cattle while the number of animals remained equal. We assumed that an increased use of wheat middlings in diets of dairy cattle inherently implied a decreased use of wheat middlings in diets of pigs. Wheat middlings are used in dairy cattle feed and pig feed for their energy content. The decreased use of wheat middlings in diets of pigs must be substituted with an alternative product while the number of pigs remained equal. 
The marginal energy-rich fodder was assumed to be barley produced in the Netherlands (Weidema 2003). Wheat middlings and barley are both products with a high energy and low protein content.

\subsubsection{Case 2: Beet tails}

Beet tails (the co-product) are cut off after first cleaning (screening and washing) of sugar beets during the production of sugar (the determining product). The production volume of beet tails, therefore, is determined by the demand for sugar.

In this case study, we illustrated the environmental consequences of increasing the use of beet tails with one ton in dairy cattle feed while the number of animals remained equal. Beet tails are used in dairy cattle feed for their energy content, but can alternatively be used for production of bio-energy. During the conversion of biomass by anaerobic digestion into biogas, methane $\left(\mathrm{CH}_{4}\right)$, carbon dioxide $\left(\mathrm{CO}_{2}\right)$ and trace gases (e.g., hydrogen gas) are produced, which can be used to produce bio-energy in the form of electricity, heat, or transport fuel (Hamelin et al. 2011; De Vries et al. 2012a). The remaining product after digestion is called 'digestate' and can be used as organic fertiliser replacing artificial fertiliser (Börjesson and Berglund 2007). We assumed that an increased use of beet tails as dairy cattle feed inherently implied a decreased use of beet tails for bio-energy production. The decreased production of electricity, heat, and digestate must be substituted with an alternative product, i.e. the marginal product. Electricity was assumed to be substituted with marginal Dutch electricity, i.e. 28\% coal-based, 67\% natural gas-based, and 5\% wind-based electricity (De Vries et al. 2012a). Fifty percent of the heat was assumed to be substituted with marginal heat, i.e. $79 \%$ natural gas-based and $21 \%$ light fuel oil-based in the Netherlands. The rest is used for digestion processes and therefore no alternative products were included (De Vries et al. 2012a). The digestate that is transported and applied to the field as fertiliser, was assumed to be substituted by marginal mineral N, P, and $\mathrm{K}$ fertiliser. Marginal production of mineral fertiliser was assumed to be calcium ammonium nitrate for $\mathrm{N}$, triple superphosphate for $\mathrm{P}_{2} \mathrm{O}_{5}$, and potassium chloride for $\mathrm{K}_{2} \mathrm{O}$ (De Vries et al. 2012a).

\subsection{Environmental consequences}

We assessed the consequences of a change in co-product use for greenhouse gas (GHG) emissions and LU. Emission of GHGs and LU were chosen as an example as the livestock sector has a significant contribution to both climate change and LU worldwide (Steinfeld et al. 2006). Emissions of GHGs regarding LUC were included, but reported separately. The following GHGs were included: $\mathrm{CO}_{2}, \mathrm{CH}_{4}$, and nitrous oxide $\left(\mathrm{N}_{2} \mathrm{O}\right)$. We assessed the change in global warming potential per ton co-product, i.e. wheat middlings or beet tails, by summing up changes 
in emissions of these GHGs based on their equivalence weighting factors in terms of $\mathrm{CO}_{2}$ (100 years' time horizon): i.e. 1 for $\mathrm{CO}_{2}, 25$ for $\mathrm{CH}_{4}$, and 298 for $\mathrm{N}_{2} \mathrm{O}$ (Forster et al. 2007).

GHG emissions associated with the production of beet tails and barley were based on data of De Vries et al. (2012b). LUC and LU data related to the cultivation of barley, were based on Tonini et al. (2012) and De Vries et al. (2012b). When computing LUC we focused on the cultivation of barley only and excluded low land use processes such as transport. Tonini et al. (2012) quantified $\mathrm{CO}_{2}$ emissions of converting, for example, forest or grassland to cropland, accounting for size and location of converted land and the types of land that were converted (biome types). De Vries et al. (2012b) assumed that 1.22 ha of land needed to be converted somewhere in the world to compensate for the use of one ha (average Dutch yield) of barley in the Netherlands. A LUC emission factor of 310 ton $\mathrm{CO}_{2}$ ha $^{-1}$ of displaced barley was derived, with an uncertainty of \pm 170 ton $\mathrm{CO}_{2}$ ha ${ }^{-1}$ (Tonini et al. 2012). This corresponds to $1.55 \mathrm{~kg} \mathrm{CO}_{2} \mathrm{~m}^{-2} \mathrm{y}^{-1}\left( \pm 0.84 \mathrm{~kg} \mathrm{CO}_{2} \mathrm{~m}^{-2} \mathrm{y}^{-1}\right)$ with an amortization period of 20 years (as prescribed in the Renewable Energy Directive (EU 2009)).

\subsection{Framework}

Figure 1 illustrates our extended framework (based on Weidema and Ekvall, 2009). The terminology used in this chapter and figures were based on Weidema and Ekvall (2009), as we extended their framework.

The multifunctional process was denoted as process $A$, where product A was the determining product. The 'process' described the environmental impact related to the product. The 'process' is referred to in italic. Process $B$ was the process related to the use of the co-product. The intermediate process (process $I$ ) was a process or series of processes between the point where the co-product left the process route of the determining product and its use in process $B$. The product produced during this intermediate process was defined as intermediate product (product I). In case product I was not available for process $B$, another product, i.e. product D, was used. Use of product I in process $B$, therefore, displaced use of product $\mathrm{D}$. The difference in environmental impact in process $B$ due to using product I instead of product D was denoted by $\Delta B$. If a co-product was not fully used, it went to waste treatment, process $W$.

Figure 1 shows the environmental consequences of three possible changes in application of a co-product. These three situations are explained below. 


\subsubsection{Situation 1: Changing the application of a co-product}

Situation 1, i.e. changing the application of a co-product from process B1a to B1b, corresponds with the first case: wheat middlings fed to dairy cattle instead of pigs. The environmental impact of this change in application is determined as:

$D 1 a-\Delta B 1 a-D 1 b+\Delta B 1 b$. Eq. 1

Parameters are explained in the following paragraphs.

\section{Computing D1a and D1b}

$D 1 a$ is the environmental impact related to the production of product D1a that is needed to replace product I in process B1a. To quantify D1a in our case of wheat middlings, we needed to determine the amount of barley required to replace $1 \mathrm{~kg}$ of wheat middlings in pig feed, and the environmental impact and LU of producing $1 \mathrm{~kg}$ of barley. Wheat middlings and barley were assumed to be exchanged on the basis of their net energy content. The available net energy in pig feed is expressed in EW (in Dutch: Energie Waarde; energy value). The EW of wheat middlings and barley were obtained from the feed tables of the Dutch Central Bureau for Livestock Feeding (CVB 2010). Wheat middlings contain $0.75 \mathrm{EW}$ per kg, whereas barley contains $1.05 \mathrm{EW}$ per $\mathrm{kg}$. To replace $1 \mathrm{~kg}$ of wheat middlings in pigs feed, we need $0.71 \mathrm{~kg}$ barley. Given a DM content of barley of 86.9\%, $621 \mathrm{~kg}$ of DM barley was needed to replace one ton of wheat middlings (i.e. $0.71 \mathrm{~kg}$ barley $\times 0.869 \times 1000=621 \mathrm{~kg}$ ). The production of $1 \mathrm{~kg}$ DM barley results in $0.44 \mathrm{CO}_{2}$-eq (excl. LUC) and a land use of $1.60 \mathrm{~m}^{2}$ (De Vries et al. 2012b).

$D 1 b$ is the environmental impact related to the production of product D1b that is avoided because of the use of product I in process $B 1 b$. To quantify $D 1 b$ in our case of wheat middlings, we needed to determine the amount of barley avoided per kg of wheat middlings in dairy cattle feed, and the environmental impact and LU of $1 \mathrm{~kg}$ of barley (similar as D1a). Just like for pigs, barley and wheat middlings were assumed to be exchanged in diet of dairy cattle on the basis of their net energy content. In the Netherlands, the available net energy in dairy cattle feed is expressed in VEM (In Dutch:Voeder Eenheid Melk; fodder unit milk). Wheat middlings contains 815 VEM per kg, whereas barley contains 975 VEM per kg (CVB 2010). To replace $1 \mathrm{~kg}$ of wheat middlings in diets of dairy cattle we needed $0.84 \mathrm{~kg}$ of barley. Given a DM content of barley of $86.9 \%, 726 \mathrm{~kg}$ of DM barley was needed to replace one ton of wheat middlings $(0.84 \mathrm{~kg}$ barley $\times 0.869 \times 1000=726 \mathrm{~kg})$.

Computing $\triangle B 1 a$ and $\triangle B 1 b$ 
$\Delta B 1 a$ is the difference in environmental impact of process B1a, i.e. feed utilization of a pig when feeding wheat middlings instead of barley. During the digestive process, ruminants, and to a minor extent monogastric animals, emit $\mathrm{CH}_{4}$ (Steinfeld et al. 2006). Changing the diet to a higher fibre composition can increase the enteric fermentation of pigs (Jensen and Jørgensen 1994). In total, however, $\mathrm{CH}_{4}$ emission from enteric fermentation of pigs is only 0.2 million ton per year compared to 2.19 for dairy cattle and 2.31 for other cattle in western Europe (Steinfeld et al. 2006). Based on these numbers, we assumed that the difference in enteric $\mathrm{CH}_{4}$ emission produced when barley instead of wheat middlings were used in diet of pigs only slightly affected emissions from process $\Delta B 1 a$ and, therefore, $\Delta B 1 a$ was set to zero.

$\Delta B 1 b$ is the difference in environmental impact of process $B 1 b$, i.e. feed utilization of a cow when feeding barley instead of wheat middlings. In dairy farming, $\mathrm{CH}_{4}$ contributes approximately $52 \%$ to total GHG emissions in the chain, mostly caused by enteric fermentation processes within the cow (Gerber et al. 2010). As the amount of enteric $\mathrm{CH}_{4}$ is related to the type and amount of feed (Dijkstra et al. 2007; Beauchemin et al. 2008; Ellis et al. 2008), we assumed a change in enteric $\mathrm{CH}_{4}$ emission by dairy cattle due to feeding wheat middlings instead of barley (i.e. $\Delta B 1 b$ ). This change in enteric $\mathrm{CH}_{4}$ emission can be computed by using IPCC Tier 2 or IPPC Tier 3 approach (IPCC 2006). IPCC Tier 2 assumed that 6.5\% of gross energy intake is converted to $\mathrm{CH}_{4}$ (IPCC 2006). As we exchanged beet tails and barley on the basis of their energy intake no difference would be found. We, therefore, preferred IPCC Tier 3, which advices to use more specific data when possible. Based on empirical relations between dry matter intake of different feed ingredients and $\mathrm{CH}_{4}$ emission factors per ingredient, enteric $\mathrm{CH}_{4}$ from dairy cattle was calculated. We adapted $\mathrm{CH}_{4}$ emission factors per feed ingredient from Vellinga et al. (2013), which are based on a mechanistic model originating from Dijkstra et al. (1992), and updated by Mills et al. (2001) and Bannink et al. (2006). For wheat middlings, enteric CH4 emission was assumed to be 20.34 gram / kg DM (DM content is 86.5\%), and for barley 22.17 gram / kg DM (Vellinga et al. 2013).

\subsubsection{Situation 2: Changing the application and the intermediate treatment}

Situation 2, i.e. changing the application from $B 1$ to $B 2$ and the intermediate process of a co-product from process I1 to $I 2$ corresponds with the second case: beet tails fed to dairy cattle instead of using it as a substrate for anaerobic digestion. The environmental impact of this change in application and intermediate process is determined as:

$D 1-\Delta B 1-I 1+I 2-D 2+\Delta B 2$.

Eq. 2

Parameters are explained in the following paragraphs. 


\section{Computing D1 and D2}

D1 is the environmental impact related to the production of product D1 that is needed to replace product I1 in process $B 1$. In our case of beet tails, multiple products are produced during the production of bio-energy and, therefore, D1 consists of two components, a and b (Figure 3). To quantify D1, we needed to determine the amount of marginal fossil based electricity, heat $(D 1 a)$ and artificial fertiliser $(D 1 b)$ required to replace the bio-energy produced and fertilising capacity provided by $1 \mathrm{~kg}$ of beet tails and the resulting digestate. Accordingly, the environmental impact of producing these marginal products was included. Electricity and heat produced from bioenergy and electricity and heat produced from fossil sources were exchanged on the basis of an equivalent amount of MJ. Electricity and heat produced from bio-energy and electricity and heat produced from fossil sources were exchanged on the basis of an equivalent amount of MJ. Digestate produced during the production of bio-energy and artificial fertiliser were exchanged on the basis of the N, P, and K fertiliser replacement value. The N fertiliser replacement value for digestate was assumed to be 65\% and for artificial fertiliser 100\% (DR 2012). Based on De Vries et al. (2012a), we assumed that the replacement value for $\mathrm{P}$ and $\mathrm{K}$ was $100 \%$ for all products. With one ton of beet tails $459 \mathrm{MJ}$ electricity, $240 \mathrm{MJ}$ heat (i.e. 50\% of the surplus heat produced) and $1.45 \mathrm{~kg} \mathrm{~N}(2.23 \times 0.65)$, $0.70 \mathrm{~kg} \mathrm{P}$, and $2.30 \mathrm{~kg} \mathrm{~K}$ in digestate, were produced (De Vries et al. 2012b). The emissions and LU data for heat and electricity production from fossil energy and artificial fertiliser production were taken from the Ecoinvent database v2.2 (EcoinventCentre, 2007).

D2 is the environmental impact related to the production of product D2 that is avoided because of the use of product I2 in process B2. To quantify D2 in our case of beet tails, we needed to determine the amount of barley avoided per kg of beet tails in dairy cattle feed, and the environmental impact and LU of barley (similar as in case 1). Just like for case 1, barley and beet tails were assumed to be exchanged in dairy cattle feed on the basis of their net energy content. Beet tails contain 106 VEM per kg, whereas barley contains 975 VEM per kg (CVB 2010). To replace $1 \mathrm{~kg}$ of beet tails in diets of dairy cattle we needed $0.11 \mathrm{~kg}$ of barley. Given a dry matter (DM) content of barley of 86.9\%, $94 \mathrm{~kg}$ of DM barley was needed to replace one ton of beet tails $(0.11 \mathrm{~kg}$ barley $\times 0.869 \times 1000=94)$.

\section{Computing $\triangle B 1$ and $\triangle B 2$}

$\Delta B 1$ is the difference in environmental impact of process $B 1$, i.e. application of fertiliser $(\Delta B 1 a)$, electricity, and heat $(\Delta B 1 b)$. We assumed that using electricity and heat produced from fossil sources instead of bio-energy will not have any impact. However, the difference in emissions during the application of artificial fertiliser instead of 
digestate has to be accounted for. Emission and LU of the application of $1 \mathrm{~kg}$ digestate and artificial fertiliser were based on data of EcoinventCentre (2007) and De Vries et al. (2012b).

$\Delta B 2$ is the difference in environmental impact of process B2, i.e. feed utilization of a cow. For dairy cattle, similar to the first example, the approach of Vellinga et al. (2013) was used. One kg beet tails DM (DM content is 13.6\%) caused 20.00 gram $\mathrm{CH}_{4}$ emission (Vellinga et al. 2013).

\section{Computing I1 and I2}

I1 is the environmental impact related to the production of product I1. Intermediate processes related to the production of bio-energy were transport of beet tails from the sugar factory to the bio-energy installation, digestion of beet tails, storage and transport of digestate and burning of bio-energy.

I2 is the environmental impact related to the production of product I2. The only intermediate process was the transport of the beet tails from the sugar fabric to the dairy cattle farm.

Emissions and LU data were taken from the EcoinventCentre v2.2 (EcoinventCentre 2007) and were based on De Vries et al. (2012b).

\subsubsection{Situation 0: a co-product that currently goes to waste will be applied in a production process.}

Situation 0 , i.e. changing from process $W$ to process $I$. Situation 0 , however, only occasionally occurs in the livestock sector because most co-products used in animal feed already had an application. We, therefore, did not further elaborate on this situation with a case but only described the affected processes. The environmental impact of situation 0 is determined as:

$I-W+\Delta B-D$.

I is the environmental impact related to the production of product I, i.e. potato peels as feed ingredient. The volume of the intermediate treatment will increase, resulting in an increase of emissions from the intermediate process $(I)$. $W$ is the environmental impact related to waste treatment. The volume of waste treatment will decrease. $\Delta B$ is the change in environmental impact of process $B$ due to using product I instead of product D. $D$ is the environmental impact related to the production of product $\mathrm{D}$. The volume of product $\mathrm{D}$, that fulfilled the application before product I, will decrease.

$<$ figure $1>$ 


\section{Results and discussion}

3.1 Results case study 1: wheat middlings fed to dairy cattle instead of pigs.

\section{Changes in land use (LU)}

Changes in LU from using one ton wheat middlings in dairy cattle feed instead of in pig feed were based on equation [1]: D1a- $\Delta B 1 a-D 1 b+\Delta B 1 b=996-0-1165+0=-169 \mathrm{~m}^{2}$ (Figure 2).

Displacing one ton wheat middlings in pig feed, required an additional production of $621 \mathrm{~kg}$ of DM barley, resulting in an increase of $996 \mathrm{~m}^{2}(\mathrm{D} 1 \mathrm{a})$. Using one ton wheat middlings as dairy cattle feed, however, displaced $726 \mathrm{~kg}$ of DM barley in dairy cattle feed, resulting in a decrease of $1165 \mathrm{~m}^{2}(D 1 b)$. No LU was related to $\Delta B$. This means in our case study, that land use was decreased with $169 \mathrm{~m}^{2}$ when one ton of wheat middlings was used in dairy cattle feed instead of in pig feed.

\section{Changes in emission of GHGs}

Changes in emission of GHGs from using one ton wheat middlings in dairy cattle feed instead of in pig feed were based on equation [1]: D1a- $\Delta B 1 a-D 1 b+\Delta B 1 b=273-0-320+37=-9 \mathrm{~kg} \mathrm{CO}$-eq

Displacing one ton wheat middlings in pig feed required an additional production of $621 \mathrm{~kg}$ of DM barley resulting in an increase in GHG emission of $273 \mathrm{~kg} \mathrm{CO}$-eq (D1a). Using one ton wheat middlings as dairy cattle feed, however, displaced $726 \mathrm{~kg}$ DM barley in dairy cattle feed resulting in a decrease of $320 \mathrm{~kg} \mathrm{CO}_{2}$-eq $(D 1 b)$.

GHG emission related to feed utilization (i.e. $\mathrm{CH}_{4}$ from enteric fermentation) was 0 for pigs $(\Delta B 1 a)$ and $37 \mathrm{~kg}$ $\mathrm{CO}_{2}$-eq for dairy cattle $(\Delta B 1 b)$. The latter value was computed given that one ton of wheat middlings as dairy cattle feed displaced $726 \mathrm{~kg}$ DM barley resulting in the emission of $16.10 \mathrm{~kg} \mathrm{CH}_{4}$ (i.e.726×22.17/1000), whereas one ton of wheat middlings (865 $\mathrm{kg} \mathrm{DM}$ ) resulted in the emission of $17.59 \mathrm{~kg} \mathrm{CH}_{4}$ (i.e. $865 \times 20.34 / 1000$ ). Therefore, enteric $\mathrm{CH}_{4}$ emission was increased with $1.49 \mathrm{~kg} \mathrm{CH}_{4}$, resulting in $37 \mathrm{~kg} \mathrm{CO}_{2}$-eq by feeding wheat middlings instead of barley to dairy cattle.

This means, in our case study, that using one ton of wheat middlings in dairy cattle feed instead of in pig feed decreased GHG emissions by 9 kg CO 2 -eq. When accounting for GHG emissions from LUC (i.e.1.22×1.55×169 $\mathrm{m}^{2}=-319 \mathrm{~kg} \mathrm{CO}$-eq), using one ton of wheat middlings in dairy cattle feed instead of in pig feed, reduced 
emissions by $329 \mathrm{~kg} \mathrm{CO}$-eq. In this case we assumed that the unused $169 \mathrm{~m}^{2}$ was used to cultivate barley, and therefore reduced the amount of forest and grassland that was converted worldwide to support the increasing demand for barley. We could also argue that the unused $169 \mathrm{~m}^{2}$ can be changed into grassland or forestland resulting in a different emission factor. It is, however, more valid to assume that the land remained in use of agricultural production and, therefore, does not result in C-sequestration. It is, however, difficult to determine the consequences of a change in diet on LUC due to the complexity of the global feed market. Furthermore, it should be noted that Tonini et al. (2012) used an uncertainty of \pm 170 ton $\mathrm{CO}_{2} \mathrm{ha}^{-1}$, resulting in a high uncertainty when LUC is incorporated in the results.

$<$ figure 2>

4.2 Results case study-2: use of beet tails in dairy cattle feed instead of using it as a substrate for anaerobic digestion

\section{Changes in land use (LU)}

Changes in LU from using one ton beet tails in dairy cattle feed instead of using it to produce bio-energy were based on equation [2]: D1a,b- $\Delta B 1 a, b-I 1+I 2-D 2+\Delta B 2=1.15-0.11-3.33+0.14-152+0=-154 \mathrm{~m}^{2}$ (Figure 3).

Reducing one ton of beet tails to produce bio-energy resulted in an increase of LU from electricity of fossil sources of $0.79 \mathrm{~m}^{2}, 0.02 \mathrm{~m}^{2}$ for heat, and $0.34 \mathrm{~m}^{2}$ for artificial fertiliser. LU related to the transport of artificial fertiliser was $<0.00$. $\left(D 1 a, b=0.79+0.02+0.34=1.15 \mathrm{~m}^{2}\right)$. Using one ton beet tails as dairy cattle feed, however, displaced $94 \mathrm{~kg}$ DM barley in dairy cattle feed, resulting in a LU of $152 \mathrm{~m}^{2}$ (D2). LU related to the intermediate process of digestion of beet tails (I1) was $0.14 \mathrm{~m}^{2}$ for transport of beet tails, $2.81 \mathrm{~m}^{2}$ for capital goods, $0.11 \mathrm{~m}^{2}$ for digestion of beet tails, $0.27 \mathrm{~m}^{2}$ for storage and transport of digestate, and no LU for burning of bio-energy. $\left(I 1=0.14+2.81+0.11+0.27=3.33 \mathrm{~m}^{2}\right)$. LU related to the intermediate process of beet tails fed to dairy cattle (I2) was the transport of beet tails, resulting in a $\mathrm{LU}$ of $0.14 \mathrm{~m}^{2}$. LU related to the application $(\Delta B 1 a)$ of the digestate was $0.13 \mathrm{~m}^{2}$ instead of $0.02 \mathrm{~m}^{2}$ for artificial fertiliser, resulting in a net $\mathrm{LU}$ of $0.11 \mathrm{~m}^{2} .\left(\Delta B 1 \mathrm{a}=0.13-0.2=0.11 \mathrm{~m}^{2}\right)$. No LU was related to $\Delta B 1 b$ and $\Delta B 2$.

This means, in our case study, that land use was decreased with $154 \mathrm{~m}^{2}$ when one ton of beet tails was used in dairy cattle feed instead of using it as a substrate for anaerobic digestion.

\section{Changes in emission of GHGs}


Changes in emission of GHGs from using one ton beet tails in dairy cattle feed instead of using it as a substrate for anaerobic digestion were based on equation [2]: D1a,b- $\Delta B 1 a, b-I 1+I 2-D 2+\Delta B 2=130-7-55+8-42+16=50 \mathrm{~kg}$ $\mathrm{CO}_{2}$-eq.

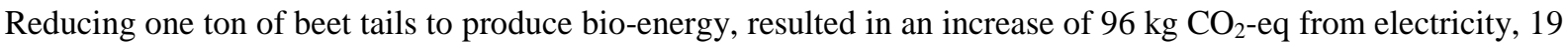
$\mathrm{kg} \mathrm{CO}$-eq from heat, and $15 \mathrm{~kg} \mathrm{CO}$-eq from artificial fertiliser. Emissions related to the transport of artificial fertiliser were $<0$. $(D 1 a, b=96+19+15=130 \mathrm{~kg} \mathrm{CO}$-eq). Using one ton beet tails as dairy feed, however, displaced $94 \mathrm{~kg}$ DM barley in dairy feed, resulting in a decrease of $42 \mathrm{CO}_{2}$-eq (D2).

GHG emissions related to the intermediate process of digestion of beet tails (I2) were $8 \mathrm{~kg} \mathrm{CO}_{2}$-eq for transport of beet tails, $2 \mathrm{~kg} \mathrm{CO}_{2}$-eq for capital goods, $20 \mathrm{~kg} \mathrm{CO}$-eq for digestion of beet tails, $22 \mathrm{~kg} \mathrm{CO}_{2}$-eq storage and transport of digestate, and $3 \mathrm{~kg} \mathrm{CO}$-eq for burning of bio-gas. $(\mathrm{I} 1=8+2+20+22+3=55 \mathrm{~kg} \mathrm{CO}$-eq). GHG emissions related to the intermediate process of beet tails fed to dairy cattle (I2) was the transport of beet tails, resulting in 8 $\mathrm{kg} \mathrm{CO}$-eq. GHG emission related to the application ( $\Delta B 1 a)$ of digestate was $15 \mathrm{~kg} \mathrm{CO}_{2}$-eq, and the application of artificial fertiliser was $8 \mathrm{~kg} \mathrm{CO}$-eq, resulting in $7 \mathrm{~kg} \mathrm{CO}$-eq. GHG emissions related to feed utilization (i.e. $\mathrm{CH}_{4}$ from enteric fermentation) was $16 \mathrm{~kg} \mathrm{CO}_{2}$-eq for dairy cattle $(\Delta B 2)$. The latter value was computed given that one ton of beet tails in diets of dairy cattle displaced $94 \mathrm{~kg}$ DM barley resulting in emission of $2.09 \mathrm{~kg} \mathrm{CH}_{4}$ (i.e.94×22.17/1000), whereas one ton of beet tail $(136 \mathrm{~kg} \mathrm{DM})$ resulted in an emission of $2.72 \mathrm{~kg} \mathrm{CH}_{4}$ (i.e.136×20/1000). Therefore, enteric $\mathrm{CH}_{4}$ emission increased by $0.63 \mathrm{~kg} \mathrm{CH}_{4}$, resulting in $16 \mathrm{~kg} \mathrm{CO}_{2}$-eq by feeding beet tails instead of barley to dairy cattle.

This means, in our case study, that using one ton of beet tails in dairy cattle feed instead of using it as a substrate for anaerobic digestion, increased GHG emissions by $50 \mathrm{~kg} \mathrm{CO}$-eq. When accounting for GHG emissions from LUC (i.e. $1.22 \times 1.55 \times-152 \mathrm{~m}^{2}=-290 \mathrm{~kg} \mathrm{CO}$-eq), using one ton of beet tails in dairy cattle feed instead of producing bio-energy, reduced emissions by $239 \mathrm{~kg} \mathrm{CO}$-eq. However, again one should take into account an uncertainty of \pm 170 ton $\mathrm{CO}_{2}$ ha $^{-1}$ and furthermore, we assumed again that the unused $154 \mathrm{~m}^{2}$ was used to cultivate barley resulting in a reduction of converted forest or grassland.

$<$ figure 3>

\section{General discussion}




\section{Nutritional requirements}

In both cases we assumed that we could replace the co-products wheat middlings and beat tails by one product (barley) based on the energy content. We based this assumption on the fact that wheat middlings, beet tails, and barley, are all used for their energy content. Nevertheless, besides energy, there are other nutritional factors which should be taken into account, such as crude protein and amino acids. Furthermore, in the composition of diets antinutritional factors and taste play a role. Increasing wheat middlings in diets of dairy cattle with one kg will most likely result in a decrease of multiple ingredients, including, for example, barley. An in-depth study is needed to analyse the nutritional consequences of changing the amount of co-products, such as wheat middling and beet tails, in diets of livestock. The same applies for the use of co-products to produce bio-energy. Beet tails are generally co-digested with manure and other substrates, but for reasons of simplicity, we focused solely on beet tails as substrate for anaerobic digestion.

\section{Framework of Weidema and Ekvall (2009) and our extended framework}

We based our framework on the theory of Weidema and Ekvall (2009). They described their procedure for dealing with multifunctional processes on the basis of Table 1 . They stated that if the demand for the determining product (product A) is increasing and if the co-product is fully used, the processed co-product (product I) will replace product D. An increase in demand for product B, for which the co-product is used, will not result in an increase of process $A$, because the production volume remains restricted to the production volume of the determining product (product A). The increased demand for product B, in this case, has to be supplied with product D.

We, however, wanted to assess the consequences of changing the application of a co-product. By doing so, we were able to analyse the optimal use of the co-products wheat middlings and beet tails. We, therefore, assumed that the demand of the determining product and product B remained equal.

$<$ table $1>$

\section{General application of the framework}

The framework provides assistance in how to evaluate the environmental impact of changing the application of a co-product. In this article, the focus was on increasing the use of co-products within the livestock sector. The theoretical framework, however, can be used also in sectors outside livestock production. For example, evaluating the environmental impact of changing the application of wood shavings, a co-product produced during the 
production of laminate, from compost to bio-energy production. It should be noted that depending on the case different impact categories can be used.

\section{Conclusion}

Based on an extended framework, we calculated the environmental consequences of using co-products in animal feed. We included environmental consequences for the alternative application of that used co-product and illustrated this by two cases: using wheat middlings as dairy cattle feed instead of pig feed, and using beet tails as dairy cattle feed instead of a substrate for anaerobic digestion. Using wheat middlings in diets of dairy cattle instead of diets of pigs resulted in a decrease of $329 \mathrm{~kg} \mathrm{CO}_{2}$-eq per ton wheat middlings and a decrease of $169 \mathrm{~m}^{2}$ land. Increasing the use of beet tails in diets of dairy cattle instead of using it as a substrate for anaerobic digestion resulted in a decrease of $239 \mathrm{~kg} \mathrm{CO}_{2}$-eq per ton beet tails and a decrease of $154 \mathrm{~m}^{2}$ land. This indicates that increasing the use of wheat middlings and beet tails in diets of dairy cattle potentially can reduce GHG emissions and LU. However, emissions from LUC had a significant impact on the results. Excluding emissions from LUC in case 1 'wheat middlings' resulted in a decrease of $9 \mathrm{~kg} \mathrm{CO}_{2}$ and an increase of $50 \mathrm{~kg} \mathrm{CO}_{2}$-eq for case 2 'beet tails’. It should, however, be noted that Tonini et al. (2012) used un uncertainty of \pm 170 ton $\mathrm{CO}_{2}$ ha $^{-1}$, resulting in a high uncertainty when LUC is incorporated in the results.

Assessing the use of co-products in the livestock sector is of importance as the results of this study show that shifting the application of a co-product, can reduce the environmental impact of the livestock sector. A correct assessment of the environmental consequences of using co-products in animal feed should also include potential changes in impacts outside the livestock sector, such as the impact in the bio-energy sector.

\section{Acknowledgment}

We want to thank Paul Bikker from Wageningen UR Livestock Research for his help on animal nutrition issues.

Furthermore we want to thank Wageningen UR Livestock Research for funding this research. 


\section{References}

Bannink A, Kogut J, Dijkstra J, France J, Kebreab E, Van Vuuren AM, Tamminga S (2006) Estimation of the stoichiometry of volatile fatty acid production in the rumen of lactating cows. J Theor Biol 238 (1):36-51

Bauman H, Tillman AM (2004) The hitchhiker's guide to LCA. Chalmers University of Technology, Goteborg, Sweden

Beauchemin KA, Kreuzer M, O’Mara F, McAllister TA (2008) Nutritional management for enteric methane abatement: a review. Aust J Exp Agric 48 (2):21-27

Börjesson P, Berglund M (2007) Environmental systems analysis of biogas systems—Part II: The environmental impact of replacing various reference systems. Biomass and Bioenerg 31 (5):326-344

CVB (2010) Tabellenboek veevoeding. CVB-reeks nr. 49. Productschap Diervoeder, Centraal Veevoederbureau, Den Haag, the Netherlands

De Vries JW, Groenestein CM, De Boer IJM (2012a) Environmental consequences of processing manure to produce mineral fertilizer and bio-energy. J Environ Manage 102:173-183

De Vries JW, Vinken TMWJ, Hamelin L, De Boer IJM (2012b) Comparing environmental consequences of anaerobic mono- and co-digestion of pig manure to produce bio-energy - A life cycle perspective. Bioresour Technol 125:239-248

De Vries M, De Boer IJM (2010) Comparing environmental impacts for livestock products: A review of life cycle assessments. Livest Sci 128 (1-3):1-11

Dijkstra J, Kebreab E, Mills JAN, Pellikaan WF, López S, Bannink A, France J (2007) Predicting the profile of nutrients available for absorption: from nutrient requirement to animal response and environmental impact. Animal 1 (01):99-111

Dijkstra J, Neal HDSC, Beever DE, France J (1992) Simulation of Nutrient Digestion, Absorption and Outflow in the Rumen: Model Description. J. Nutr. 122 (11):2239-2256

DR (2012) Regulations for the use of organic manure, Dienst Regelingen, Ministry of Economic Affairs, Agriculture and Innovation. http://www.hetlnvloket.nl/onderwerpen/mest. Accessed 28-01-2013

EcoinventCentre (2007) Ecoinvent data v2.2 Final reports econinvent 2007. Swiss Centre for Life Cycle Inventories, Dübendorf, Switzerland

Ekvall T, Finnveden G (2001) Allocation in ISO 14041—a critical review. J Clean Prod 9 (3):197-208

Ekvall T, Weidema B (2004) System boundaries and input data in consequential life cycle inventory analysis. Int J LCA 9 (3):161-171 
Elferink EV, Nonhebel S, Moll HC (2008) Feeding livestock food residue and the consequences for the environmental impact of meat. J Clean Prod 16 (12):1227-1233

Ellis JL, Dijkstra J, Kebreab E, Bannink A, Odongo NE, Mcbride BW, France J (2008) Aspects of rumen microbiology central to mechanistic modelling of methane production in cattle. J Agric Sci 146 (Special Issue 02):213-233

EU (2009) Directives on the promotion of the use of energy from renewable sources. Directive 2009/28/EC.
European
Parliament,
Brussels,
Belgium.

http://europa.eu/legislation_summaries/energy/renewable_energy/en0009_en.htm. Accessed 28-1-2013

Fadel JG (1999) Quantitative analyses of selected plant by-product feedstuffs, a global perspective. Anim Feed Sci Technol 79 (4):255-268

Forster P, Ramaswamy V, Artaxo P, Berntsen T, Betts R, Fahey DW, Haywood J, Lean J, Lowe DC, Myhre G, Nganga J, Prinn R, Raga G, Schulz M, Van Dorland R (2007) Changes in Atmospheric Constituents and in Radiative Forcing. Climate Change 2007: The Physical Science Basis. Cambridge University Press, Cambridge, United Kingdom and New York, NY, USA

Garnett T (2009) Livestock-related greenhouse gas emissions: impacts and options for policy makers. Environ Sci Pol 12 (4):491-503

Gerber P, Vellinga T, Opio C, Henderson B, Steinfeld H (2010) Greenhouse Gas Emissions from the Dairy Sector, A Life Cycle Assessment. Food and Agriculture Organization (FAO), Rome, Italy

Guinée JB, Gorrée M, Heijungs R, Huppes G, Kleijn R, De Koning A, Van Oers L, Wegener Sleeswijk A, Suh S, Udo De Haes HA, De Bruijn H, Van Duin R, Huijbregts MAJ, Lindeijer E, Roorda AAH, Van der Ven BL, Weidema BP (2002) Life Cycle Assessment: An operational guide to the ISO standards. Centrum voor Milieukunde, Leiden University, Leiden, the Netherlands

Hamelin L, Wesnæs M, Wenzel H, Petersen BM (2011) Environmental Consequences of Future Biogas Technologies Based on Separated Slurry. Environ Sci Technol 45 (13):5869-5877

IPCC (2006) Intergovernmental Panel on Climate Change. Guidelines for National Greenhouse Gas Inventories. Volume 4: Agriculture, forestry and other land use. Prepared by the National Greenhouse Gas Inventories Program, Eggleston H.S., Buendia L., Miwa K., Ngara T. and Tanabe K. (eds). Published: IGES, Japan ISO14040 (1997) Environmental management - life cycle assessment: Principles and framework. European Committee for Standardization (CEN), Brussels, Belgium 
ISO14041 (1998) Environmental management - life cycle assessment: Goal and scope definition and inventory analysis. European Committee for Standardization (CEN), Brussels, Belgium

ISO14042 (2000) Environmental management - life cycle assessment: Life cycle impact assessment. Committee for Standardization (CEN), Brussels, Belgium

ISO14043 (2000) Environmental management - life cycle assessment: Life cycle interpretation. European Committee for Standardization (CEN), Brussels, Belgium

Jensen BB, Jørgensen H (1994) Effect of dietary fiber on microbial activity and microbial gas production in various regions of the gastrointestinal tract of pigs. Appl Environ Microbiol 60 (6):1897-1904

Koppejan J, Elbersen W, Meeusen M, Bindraban P (2009) Availability of Dutch biomass for electricity and heat in 2030 (Beschikbaarheid van Nederlandse biomassa voor elektriciteit en warmte in 2030). Procede BIOMASS BV, Enschede, the Netherlands, $\underline{\text { http://groengas.nl/wp- }}$ content/uploads/2011/09/Beschikbaarheid-van-Nederlandse-biomassa-voor-warmte-en-elektriciteit-in2020.pdf

Mills JA, Dijkstra J, Bannink A, Cammell SB, Kebreab E, France J (2001) A mechanistic model of whole-tract digestion and methanogenesis in the lactating dairy cow: model development, evaluation, and application. J Anim Sci 79 (6):1584-1597

Nonhebel S (2007) Energy from agricultural residues and consequences for land requirements for food production. Agricul Syst 94 (2):586-592

Steinfeld H, Gerber P, Wassenaar T, Castel V, Rosales M, De Haan C (2006) Livestock's long shadow: environmental issues and options. Food and Agriculture Organization (FAO), Rome, Italy

Tilman D, Fargione J, Wolff B, D'Antonio C, Dobson A, Howarth R, Schindler D, Schlesinger WH, Simberloff D, Swackhamer D (2001) Forecasting Agriculturally Driven Global Environmental Change. Science 292 (5515):281-284

Tonini D, Hamelin L, Wenzel H, Astrup T (2012) Bioenergy production from perennial energy crops: A consequential LCA of 12 bioenergy scenarios including land use changes. Environ Sci Technol 46 (24):13521-13530

Van der Werf HMG, Petit J, Sanders J (2005) The environmental impacts of the production of concentrated feed: the case of pig feed in Bretagne. Agricul Syst 83 (2):153-177 
Vellinga T, Van Laar H, Thomassen MA, De Boer IJM, Berkhout P, Aiking H (2009) Environmental impact of animal feed (Milieueffecten van diervoeders). Rapport 205, Animal Sciences Group van Wageningen UR, Lelystad, the Netherlands, http://edepot.wur.nl/5362

Vellinga TV, Blonk H, Marinussen M, Van Zeist WJ, De Boer IJM (2013) Methodology used in feedprint: a tool quantifying greenhouse gas emissions of feed production and utilization. Lelystad, the Netherlands, http://edepot.wur.nl/254098

Weidema BP (2003) Market information in life cycle assessment. Project No. 863, Danish Environmental Protection Agency, Copenhagen, Denmark

Weidema BP, Ekvall T, Heijungs R (2009) Guidelines for applications of deepened and broadened LCA. 2.-0 LCA consultants, Aalborg, Denmark, http://www.leidenuniv.nl/cml/ssp/publications/calcas_report_d18.pdf 
Table 1 Equations for dealing with multifunctional processes, based on Weidema and Ekvall, 2009, p15

Processes affected by a change in demand for: Product A Product B

Dependent co-product fully utilised

$\mathrm{A}+\mathrm{I}-\mathrm{D}+\Delta \mathrm{B}$

$\mathrm{D}+\mathrm{B}$ 


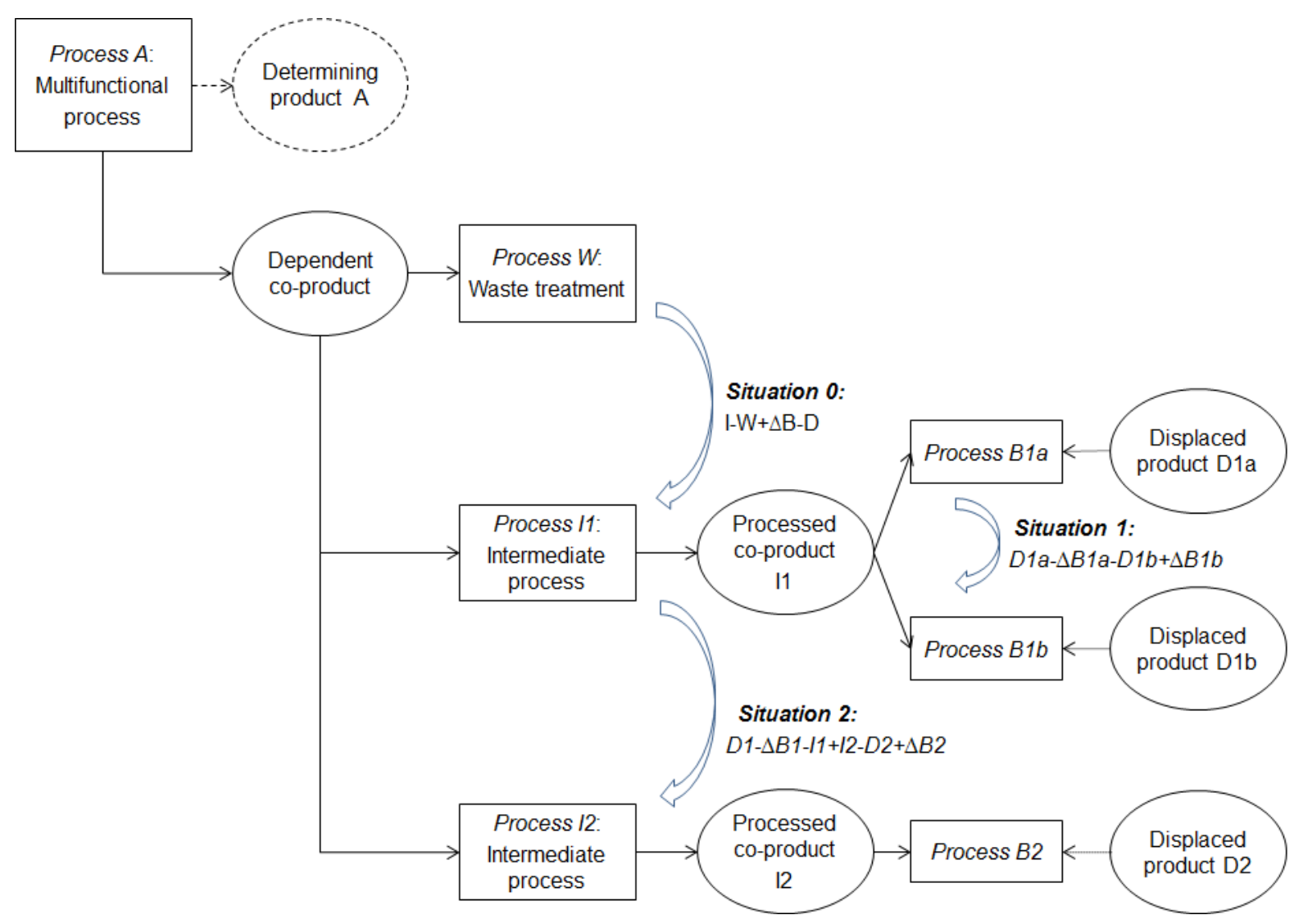

Figure 1 Framework for assessing environmental consequences of changing the application of co-products in diets of livestock while the production of product A and B remains the same, three different situations (Based on Weidema and Ekvall, 2009) 


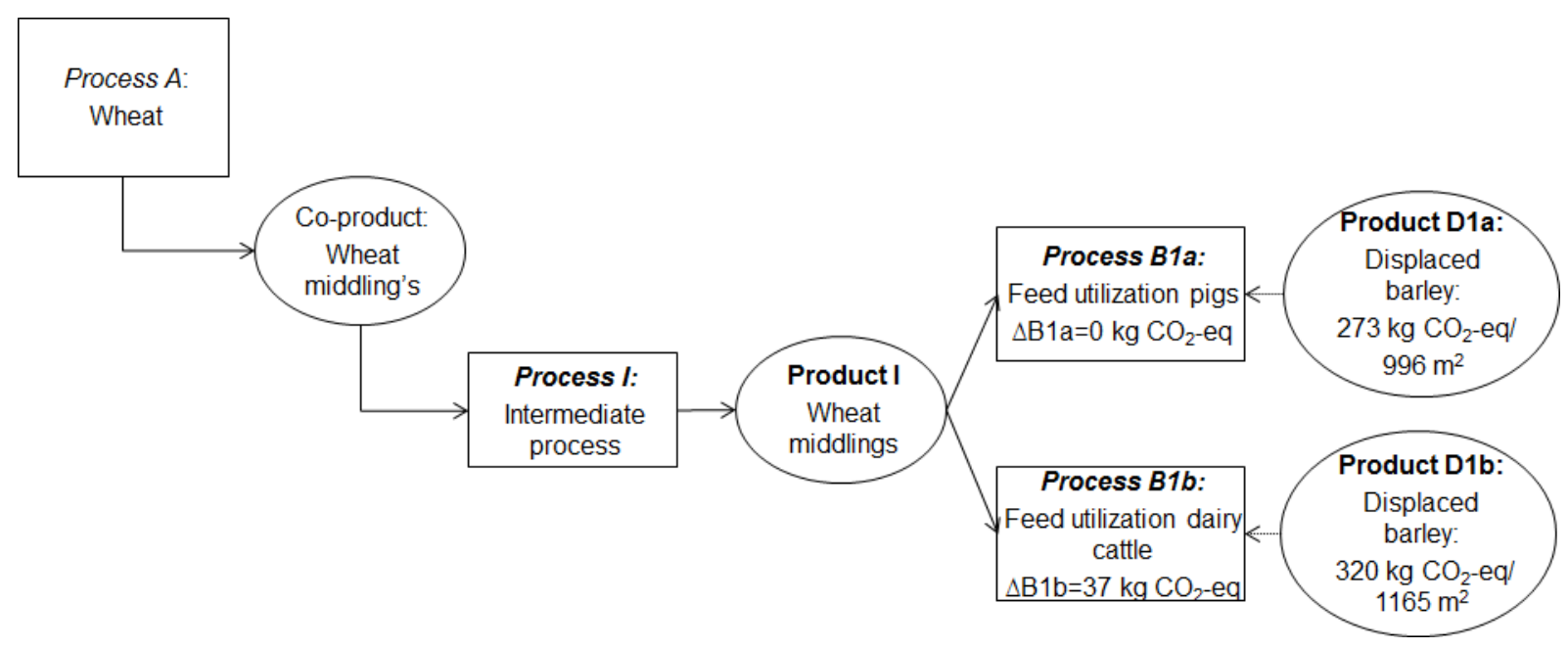

Figure 2 Processes that are affected by using one ton of wheat middlings as dairy cattle feed instead of using it as pig feed (Situation 1, Eq.: D1a- $\Delta B 1 a-D 1 b+\Delta B 1 b$ ) 


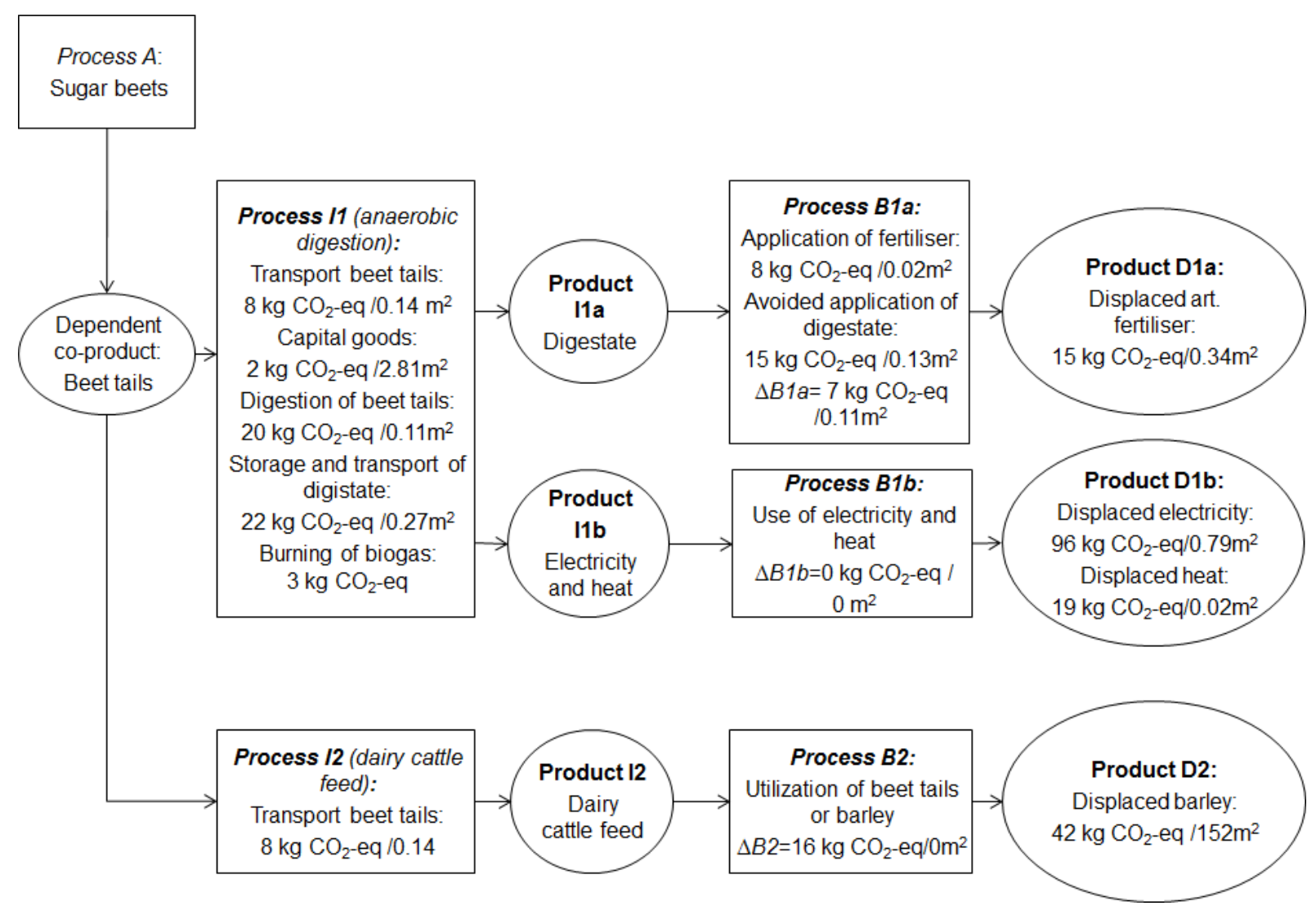

Figure 3 Processes that are affected by using one ton of beet tails as dairy cattle feed instead of using it as a

substrate for anaerobic digestion (Situation 2, Eq.: D1a,b- $\Delta B 1 a, b-I 1+I 2-D 2+\Delta B 2$ ) 